\title{
ANALISIS PENGENDALIAN INTERN PIUTANG USAHA UNTUK MEMINIMALKAN PIUTANG TAK TERTAGIH (BAD DEBT) PADA PT.WAHANA OTTOMITRA MULTIARTHA, TbK CABANG MADIUN
}

\author{
Anny Widiasmara \\ Email : anny.asmara@gmail.com
}

\begin{abstract}
Abstrak : Penelitian ini bertujuan untuk mengetahui pelaksanaan pengendalian intern piutang usaha untuk meminimalkan piutang tak tertagih (bad debt) pada PT. Wahana Ottomitra Multiartha, Tbk cabang Madiun. Perkembangan dunia usaha dan persaingan bisnis yang semakin kompetitif seiring pertumbuhan perekonomian dan teknologi yang semakin pesat dalam era globalisasi menuntut perusahaan bekerja lebih keras untuk meningkatkan kinerja, mengembangkan inovasi dan melakukan perluasan usaha agar dapat terus bertahan dan bersaing untuk mencapai tujuan yang dikehendaki perusahaan., salah satunya dengan melakukan penjualan secara kredit sehingga menimbulkan piutang terhadap konsumen. Piutang usaha suatu perusahaan pada mumnya merupakan bagian terbesar dari aset lancar. Tujuan yang ingin dicapai dari penelitian ini adalah untuk mengetahui pelaksanaan pengendalian intern piutang usaha untuk meminimalkan piutang tak tertagih (bad debt). Pendekatan yang digunakan dalam penelitian ini adalah pendekatan kualitatif. Dalam penelitian ini, peneliti melakukan analisis pengendalian intern piutang usaha dengan melakukan analisis terhadap rasio Receivable Turn Over, Average Collection Period, Aging of Account Receivable. Hasil dalam penelitian ini Secara keseluruhan, prosedur pengendalian intern terhadap piutang usaha pada PT.WOM Finance,Tbk cabang Madiun berjalan cukup efektif total piutang tak tertagih tahun 2013 sebesar $3.58 \%$, piutang yang dapat ditagih selama periode 2013 sebesar $96.42 \%$. Hal ini menunjukkan bahwa dengan dilakukannya pengendalian intern terhadap piutang usaha, kualitas booking AR dan kualitas penagihan mengalami perbaikan terus menerus sehingga dapat meminimalkan piutang tak tertagihnya dan berhasil membukukan profit sesuai dengan tujuan yang ditetapkan oleh perusahaan.
\end{abstract}

Kata kunci : pengendalian, internal, piutang.

Anny Widiasmara, adalah Dosen Sekolah Tinggi Ilmu Ekonomi Dharma Iswara Madiun 


\section{PENDAHULUAN}

Perkembangan dunia usaha dan persaingan bisnis yang semakin kompetitif seiring pertumbuhan perekonomian dan teknologi yang semakin pesat dalam era globalisasi menuntut perusahaan bekerja lebih keras untuk meningkatkan kinerja, mengembangkan inovasi dan melakukan perluasan usaha agar dapat terus bertahan dan bersaing untuk mencapai tujuan yang dikehendaki perusahaan. Perusahaan yang mampu menghadapi persaingan akan dapat terus bertahan, sebaliknya perusahaan yang tidak mampu bersaing akan mengalami kebangkrutan. Kegiatan penjualan baik tunai maupun kredit merupakan aktivitas yang penting bagi perusahaan dalam mencapai tujuan utama yaitu memperoleh laba yang optimal.

Pada umumnya, perusahaan akan lebih menyukai penjualan secara tunai daripada secara kredit, namun tekanan-tekanan persaingan telah memaksa kebanyakan perusahaan untuk menawarkan kredit. Demikian halnya dengan PT. Wahana Ottomitra Multiartha, Tbk cabang Madiun, sebuah perusahaan pembiayaan yang dalam kegiatan usahanya melakukan pembiayaan pembelian kendaraan bermotor secara kredit, memiliki visi "Menjadi perusahaan pembiayaan empat teratas terbaik dengan memberikan kualitas sehingga menciptakan kepuasan kepada stakeholder dan laba yang berkelanjutan kepada sharesholder”. Maka PT. Wahana Ottomitra Multiartha, menerapkan pengendalian piutang dengan cara menganalisa setiap calon debitur, pemisahan antara divisi penjualan dan divisi kredit yang berperan sebagai fungsi pengesahan kredit, serta control dari divisi collection dengan harapan dapat menekan resiko piutang tak tertagih ( $b a d$ debt).

Berdasarkan latar belakang bahwa pengendalian intern piutang perlu dilaksanakan agar piutang tak tertagih (bad debt) dapat ditekan, maka masalah yang akan diteliti dapat dirumuskan sebagai berikut: Bagaimana pelaksanaan pengendalian intern piutang usaha untuk meminimalkan piutang tak tertagih (bad debt) pada PT. Wahana Ottomitra Multiartha, Tbk cabang Madiun ,tujuan dari penelitian ini adalah sebagai berikut :Untuk mengetahui pelaksanaan pengendalian intern piutang usaha untuk meminimalkan piutang tak tertagih (bad debt) pada PT.Wahana Ottomitra Multiartha, Tbk cabang Madiun.

\section{TINJAUAN PUSTAKA \\ Piutang Usaha}

Piutang Usaha (Account Receivable) merupakan jumlah yang terutang oleh pembeli yang timbul karena penjualan kepadanya barang dagangan atau jasa atau aktiva lainnya yang dilakukan secara kredit. Sebagian besar perusahaan menjual secara kredit agar dapat menjual lebih banyak produk atau jasa. Menurut Farah Margaretha (2011:57) yang dimaksud dengan Piutang yaitu : "Piutang adalah aktiva atau kekayaan yang timbul sebagai akibat dari dilaksanakannya penjualan secara kredit". Dari beberapa pengertian diatas dapat disimpulkan bahwa piutang merupakan hak atau klaim perusahaan terhadap klien atau pelanggan atas penjualan barang atau jasa secara kredit.

\section{Penggolongan Piutang}

Pengklasifikasian piutang dilakukan untuk memudahkan pencatatan transaksi yang mempengaruhinya. Menurut Rudianto (2012:210) berdasarkan jenis dan 
asalnya piutang dalam perusahaan dapat diklasifikasikan menjadi dua kelompok yaitu:

1) Piutang Usaha

Merupakan piutang yang timbul dari penjualan barang dan jasa yang dihasilkan perusahaan.

2) Piutang Bukan Usaha

Merupakan piutang yang timbul bukan sebagai akibat dari penjualan barang atau jasa yang dihasilkan perusahaan.

\section{Pengakuan Piutang}

Pengakuan piutang usaha terjadi jika perusahaan menjual produk secara kredit atau memberi jasa namun belum terjadi pembayaran kepada perusahaan. Istilah pengakuan itu sendiri mengandung arti "proses pembentukan suatu pos yang memenuhi definisi unsur serta kriteria pengakuan dalam neraca atau laporan laba rugi”. (Ikatan Akuntansi Indonesia 2004:19). Pengakuan piutang usaha sering berhubungan dengan pengakuan pendapatan. Karena pengakuan pendapatan pada umumnya dicatat ketika proses menghasilkan laba telah selesai dan kas terealisasi atau dapat direalisasi, maka piutang yang berasal dari penjualan barang umumnya diakui pada waktu hak milik atas barang beralih ke pembeli.

\section{Kebijakan Pengelolaan Piutang}

Dalam perkembangannya sebuah perusahaan memiliki dua sasaran yang saling bertentangan mengenai piutang. Disatu sisi perusahaan ingin melakukan sebanyak mungkin penjualan kredit guna memperluas pangsa pasar. Namun disisi lain piutang merupakan aktiva yang tidak produktif, yang tidak menghasilkan pendapatan (kas) hingga saat penagihannya terlunasi. Dan semuanya itu akan teratasi dengan adanya kebijakan penjualan kredit yang baik antara lain :

1) Kebijakan periode kredit, yaitu jangka waktu antara terjadinya penjualan hingga tanggal jatuh tempo pembayaran

2) Kebijakan diskon yang diberikan untuk mendorong pembayaran yang lebih cepat

3) Kebijakan standar kredit, yaitu persyaratan minimum atas kemampuan keuangan dari para pelanggan agar bisa membeli secara kredit.

4) Kebijakan mengenai penagihan, yaitu sampai sejauh mana tindakan atau kelonggaran yang diberikan perusahaan atas piutang yang tidak dibayar pada waktunya

\section{Cara Pengumpulan Piutang}

Pengumpulan piutang suatu perusahaan merupakan prosedur yang harus diikuti dalam mengumpulkan piutang-piutangnya apabila sudah jatuh tempo.

\section{Analisis Umur Piutang}

Untuk mengevaluasi kinerja dan mengetahui efisien tidaknya investasi dalam piutang perlu dilakukan penilaian. Alat yang sering dipakai adalah rasio atau indeks yang menghubungkan dua data keuangan yang satu dengan yang lainnya.

Rasio menggambarkan suatu hubungan atau perimbangan antara suatu jumlah tertentu dengan jumlah yang lain dengan menggunakan alat analisa berupa rasio ini, 
yang dapat menjelaskan atau memberi gambaran kepada penganalisa tentang baik atau buruknya keadaan atau posisi keuangan.

Rasio keuangan untuk menilai investasi pada piutang menurut Wild,Subramanyam,Halsey (2005:197) adalah sebagai berikut. :

1) Rasio Perputaran Piutang (Receivable Turn Over )

Piutang yang dimiliki suatu perusahaan mempunyai hubungan yang erat dengan volume penjualan kredit.

Menghitung Rasio Perputaran Piutang (Receivable Turn Over)

$$
\text { Perputaran piutang }=\frac{\text { Penjualan kredit bersih }}{\text { Rata }- \text { rata piutang }}
$$

Dimana, untuk menghitung rata-rata piutang adalah

$$
\text { Rata-rata piutang }=\frac{\text { Saldo awal piutang }+ \text { Saldo akhir piutang }}{2}
$$

Tinggi rendahnya receivable turnover mempunyai efek langsung terhadap besar kecilnya dana yang diinvestasikan dalam piutang. Makin tinggi turnover, berarti makin cepat perputarannya, yang berarti makin pendek waktu terikatnya dana dalam piutang, sehingga untuk mempertahankan net credit sales tertentu, dengan naiknya turnover, dibutuhkan jumlah dana lebih kecil untuk diinvestasikan dalam piutang.

2) Umur rata-rata piutang (Average Collection Period)

Rasio ini berfungsi untuk mengetahui rata-rata hari yang diperlukan untuk mengumpulkan piutang dan mengubahnya menjadi kas.

Menghitung umur rata-rata piutang (Average collection Period)

$$
\text { Umur Rata-rata piutang }=\frac{360 \text { hari }}{\text { perputaran piutang }}
$$

Untuk mengevaluasi kebijakan penagihan maka pendekatan yang popular digunakan adalah umur piutang usaha (Aging of Account Receivable)

Aging of Account Receivable adalah sebuah teknik pemantauan kredit yang menggunakan jadwal yang menunjukkan prosentase terhadap total sisa account receivable yang masih belum dibayarkan untuk periode waktu tertentu. Tujuan teknik ini adalah untuk mengetahui problemnya secara tepat. Misalnya perusahaan memiliki net 30 dengan ACP (minus penerimaan, pemrosesan dan pencairan) 50 hari, berarti ACP perusahaan itu terlalu tua.

\section{Metode Penghapusan Piutang}

Diantara banyak debitur perusahaan pasti ada diantaranya yang tidak dapat melaksanakan kewajibannya untuk membayar utangnya kepada perusahaan. 
Menurut Ahmad Syafi'i Syakur dalam bukunya Intermediate Accounting (2009:96) : "Metode penghapusan piutang adalah penghapusan piutang yang tidak dapat ditagih, dikarenakan debiturnya tidak dapat membayar utangnya karena bangkrut, meninggal, pailit dan lain-lain . Kerugian penghapusan ini akan dimasukkan sebagai biaya usaha perusahaan. Untuk mencatat penghapusan piutang usaha tersebut dapat dilakukan dengan dua metode, yaitu :

1) Metode Penghapusan Langsung (Direct Write Off Methode)

2) Metode Cadangan (Allowance Method)

\section{KREDIT}

\section{Pengertian Kredit}

Kata kredit berasal dari bahasa Yunani yaitu "credere", yang artinya percaya atau to trust atau dalam bahasa Latin "creditum" yang berarti kepercayaan akan kebenaran. Oleh karena itu, dasar pemberian kredit oleh suatu bank atau lembaga pembiayaan kepada seorang debitur adalah kepercayaan. Menurut pasal 1 ayat 11 UU No.10/1998 tentang Perubahan UU No.10/1992 tentang perbankan "Kredit adalah penyediaan uang atau tagihan yang dapat di persamakan dengan itu, berdasarkan persetujuan atau kesepakatan pinjam meminjam antara bank dengan pihak lain yang mewajibkan pihak peminjam untuk melunasi hutangnya setelah jangka waktu tertentu dengan pemberian bunga, imbalan atau pengembalian hasil keuntungan".

\section{Komponen Kebijakan Kredit.}

Menurut I Made Sudana (2011:218) Jika perusahaan memutuskan untuk memberikan kredit kepada pelanggannya, perusahaan harus menentukan prosedur untuk memperoleh kredit dan pelunasannya yang dituangkan dalam kebijakan kredit, yang meliputi hal berikut:
(a) Syarat penjualan
(b) Analisis kredit
(c) Kebijakan penagihan piutang

\section{Teknik Analisis Kredit}

Untuk dapat melaksanakan kegiatan perkreditan yang sehat dikenal adanya prinsip "5C". Prinsip tersebut digunakan untuk menghindari maupun untuk memperkecil resiko kredit yang mungkin terjadi. Menurut Farah Margaretha (2011:53) metode analisis 5C yang digunakan untuk mengukur kualitas kredit adalah sebagai berikut :

1) Karakter (Character)

Merupakan penelitian atas kepribadian pelanggan yang menunjukkan kemungkinan bahwa pelanggan secara jujur dan sadar mau memenuhi kewajibannya. Semua itu menjadi ukuran "kemauan" membayar.

\section{2) Kemampuan (Capacity)}

Merupakan penilitian subjektif atas pelanggan untuk membayar kredit beserta bunganya tepat pada waktu yang telah disepakati. Alat ukurnya adalah catatan prestasi bisnis yang telah dilengkapi dengan pengamatan langsung di pabrik/kantor pelanggan. 


\section{3) Modal (Capital)}

Merupakan penilaian kekuatan finansial yang dilengkapi oleh pelanggan. Alat ukurnya adalah laporan keuangan.

\section{4) Jaminan (Collateral)}

Merupakan bentuk aktiva yang diberikan oleh pelanggan sebagai jaminan keamanan atas kredit yang diberikan.

\section{5) Kondisi (Conditions)}

Merupakan gambaran/dampak perubahan kondisi perekonomian secara umum maupun industri terhadap kemampuan pelanggan untuk memenuhi kewajibannya.

\section{Penyebab Kredit Bermasalah}

1) Faktor Kelemahan

a. Kelemahan perusahaan dalam menganalisis, sehingga salah dalam membuat keputusan pemberian kredit;

b. Kelemahan perusahaan dalam melakukan pengawasan;

c. Kelemahan nasabah dalam menggunakan dana pinjaman.

2) Faktor Moral

a. Tindakan internal perusahaan yang dengan sengaja tidak menerapkan prinsip kehati-hatian;

b. Tindakan internal perusahaan yang dengan sengaja tidak menerapkan praktek perbankan yang sehat;

c. Tindakan nasabah yang dengan sengaja untuk merugikan perusahaan.

3) Faktor Keadaan

a. Adanya risiko bisnis yang tidak terelakan;

b. Adanya kebijakan Pemerintah yang berpengaruh buruk terhadap bisnis atau aktifitas nasabah;

c. Adanya musibah atau bencana yang tidak dapat dihindari.

\section{Penyelamatan Kredit Bermasalah}

Dalam usaha mengatasi timbulnya kredit bermasalah, pihak perusahaan dapat melakukan beberapa tindakan penyelamatan yaitu :

a. Penjadwalan ulang (Rescheduling)

Rescheduling adalah penjadwalan kembali sebagian atau seluruh kewajiban debitur.

b. Persyaratan ulang (Reconditioning).

Reconditioning adalah perubahan sebagian atau seluruh syarat-syarat kredit yang tidak terbatas pada perubahan jadwal pembayaran.

c. Penataan ulang (Restructuring)

Restructuring adalah usaha penyelamatan kredit yang terpaksa harus dilakukan bank dengan cara mengubah komposisi pembiayaan yang mendasari pemberian kredit.

d. Eksekusi barang jaminan

Yaitu penjualan barang-barang yang dijadikan jaminan dalam rangka pelunasan utang. 
Menurut Taswan (2010:456) restrukturisasi kredit penting dalam upaya penyelamatan kredit bermasalah karena melalui restrukturisasi kredit sangat memungkinkan usaha debitur terus berjalan. Solusi ini dianggap terbaik saat ini sebab disamping menyelamatkan dana perbankan dan menyelamatkan usaha debitur juga memberikan manfaat bagi masyarakat pada umumnya karena penyelamatan kredit dapat ikut mendukung recovery ekonomi nasional.

\section{PENGENDALIAN INTERN}

1. Pengertian Pengendalian Intern

Pengertian Pengendalian internal menurut beberapa pendapat :

1) Munawir (2004:72) : Pengendalian intern meliputi rencana organisasi serta semua cara dan ketentuan-ketentuan yang dikoordinasikan, yang digunakan didalam perusahaan untuk melindungi harta milik perusahaan, memeriksa ketelitian dan kebenaran data akuntansi, meningkatkan efisiensi didalam operasi dan mendorong dipatuhinya kebijaksanaan perusahaan yang telah ditetapkan.

2) Ahmad Syafi'i Syakur (2009:95): Pengendalian Intern adalah tindakan preventif atas keselamatan piutang dagang dari adanya kemungkinan piutang tidak tertagih, keterlambatan penagihan dan penyalahgunaan

Dari beberapa pengertian diatas dapat disimpulkan bahwa, pengendalian intern didefinisikan sebagai suatu proses, yang dipengaruhi oleh sumber daya manusia dan sistem teknologi informasi, yang dirancang untuk membantu organisasi mencapai suatu tujuan atau objektif tertentu.

\section{Pengendalian Intern terhadap Piutang Usaha}

Pengendalian intern terhadap piutang usaha sebagai tindakan preventif atas keselamatan piutang usaha dari adanya kemungkinan piutang tak tertagih, keterlambatan penagihan dan penyalahgunaan piutang oleh karyawan. Ditinjau dari cara pendekatan manajemen preventif, maka ada tiga bidang pengendalian yang umum pada titik mana dapat diambil tindakan untuk mewujudkan pengendalian piutang. Ketiga bidang itu adalah :

1) Pemberian kredit dagang

2) Penagihan (Collections)

3) Penetapan dan penyelenggaraan pengendalian intern yang layak.

\section{Unsur-unsur Pengendalian Internal}

Menurut Munawir (2004:74) ada empat unsur pokok yang harus dipenuhi untuk menciptakan sistem Pengendalian Intern yang memuaskan dalam perusahaan yaitu sebagai berikut :

1) Struktur Organisasi yang memisahkan tanggung jawab fungsional secara tepat, jelas dan tegas.

2) Suatu sistem otorisasi dan prosedur pencatatan yang cukup baik yang memungkinkan untuk mengadakan pengawasan akuntansi terhadap harta milik, hutang, pendapatan serta biaya. 
3) Adanya praktek yang sehat dalam melaksanakan tugas dan fungsi setiap bagian di dalam organisasi itu.

4) Suatu tingkat kecakapan karyawan yang sesuai dengan syarat yang diminta oleh tanggung jawabnya.

Menurut Jurnal Nabila Habibie (2013) COSO menyebutkan pengendalian internal terdiri dari 5 (lima) komponen yang saling berhubungan. Adapun 5 (lima) komponen pengendalian internal tersebut adalah :

1) Lingkungan Pengendalian (Control Environment)

2) Penentuan Resiko (Risk Assesment)

3) Aktivitas Pengendalian (Control Procedure)

4) Informasi dan Komunikasi (Information and Communication)

5) Pengawasan atau Pemantauan (Monitoring)

\section{Tujuan Pengendalian Intern atas Piutang}

Pemberian piutang dimaksudkan untuk meningkatkan volume penjualan bagi sebuah perusahaan. Diharapkan dengan meningkatnya volume pejualan, maka sebuah perusahaan dapat memperoleh keuntungan. Namun ada beberapa resiko atas keberadaan piutang itu sendiri yang dapat merugikan perusahaan. Oleh karena itu perlu adanya pengendalian standar yang telah ditetapkan, maka perusahaan perlu melakukan perbaikan.

Menurut Mulyadi (2001:163) tujuan sistem pengendalian intern adalah :

1) Menjaga kekayaan organisasi

2) Mengecek ketelitian dan keandalan data akuntansi

3) Mendorong efisiensi

4) Mendorong dipatuhinya kebijakan manajemen.

\section{Manfaat Pengendalian Piutang Usaha dalam Meminimalkan Resiko} Piutang Tak Tertagih pada perusahaan Leasing

Mendeteksi kemungkinan kredit bermasalah dapat dimulai saat kreditur melakukan analisa terhadap calon debitur ketika mengajuan permohonan fasilitas kredit. Deteksi awal kredit bermasalah adalah hal yang sangat penting, karena kredit bermasalah merupakan sumber utama meningkatnya piutang tak tertagih. Makin tinggi rasio piutang tak tertagih dan jumlah unit tarik barang akan menjadi masa kritis bagi kelangsungan usaha perusahaan.

\section{Penelitian Terdahulu}

Ticke Fandarani (2012) melakukan penelitian dengan judul Analisis pengendalian internal atas penjualan kredit dan piutang usaha Pada PT. Mitra Sejati Beribu. Ticke Fandarani menggunakan metode deskriptif dan komparatif dalam melakukan analisa data. Hasil penelitian Ticke Fandarani menunjukkan perusahaan tersebut masih memiliki kelemahan-kelemahan dalam kegiatan penjualan kredit dan piutang usahanya. Nabila Habibie (2013) dalam penelitiannya yang berjudul Analisis pengendalian intern piutang usaha pada PT.Adira Finance Cabang Manado menggunakan uji dekriptif kualitatif terhadap kuesioner pengendalian intern piutang usaha yang menyangkut dengan system pengendalian 
intern model COSO. Hasil pengujian menunjukkan secara keseluruhan pengendalian intern piutang usaha pada PT.Adira Manado sudah berjalan efektif,dimana manajemen perusahaan sudah menerapkan konsep dan prinsipprinsip pengendalian intern, namun disisi lain terdapat beberapa prosedur yang belum mencerminkan konsep pengendalian intern.

\section{Kerangka Pemikiran}

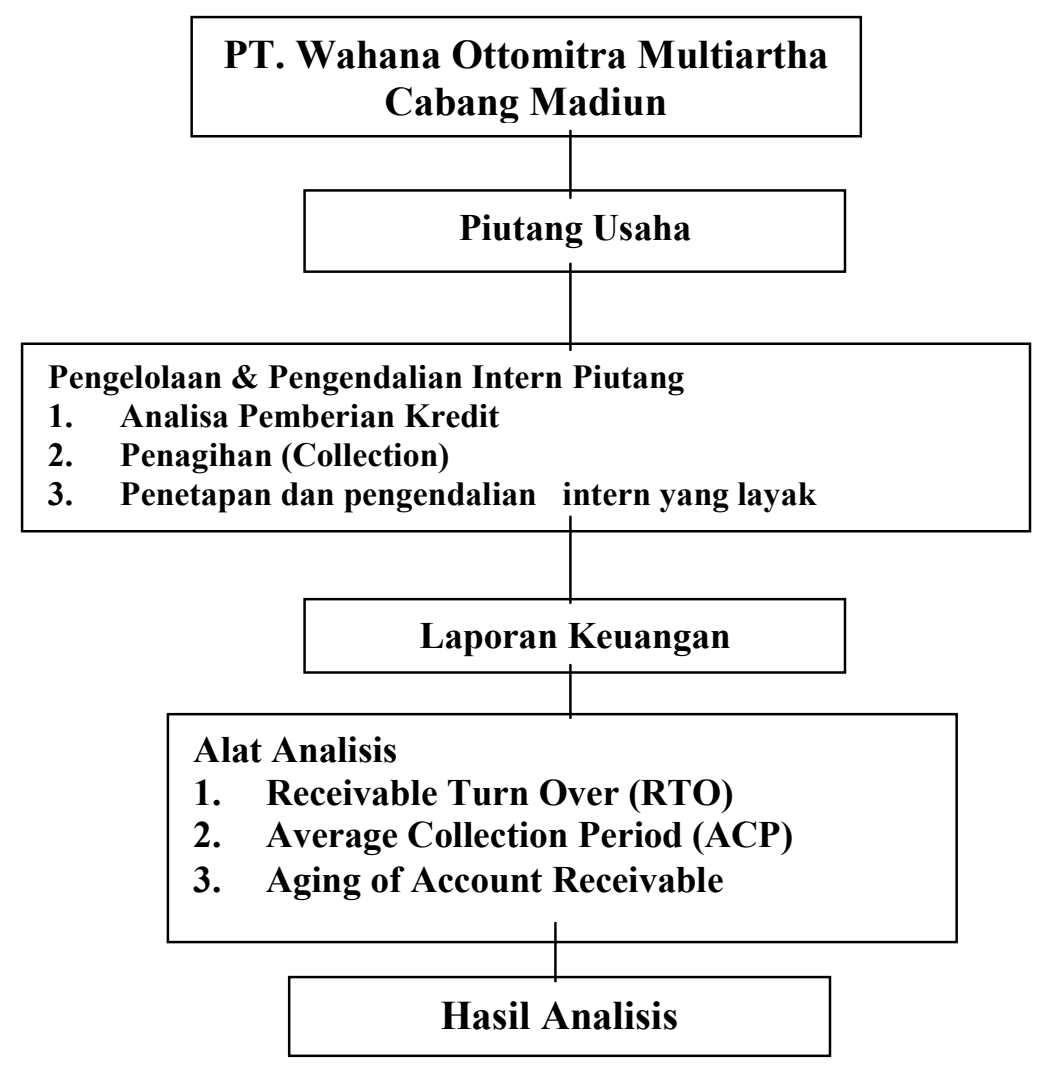

Gambar 1. Kerangka Pemikiran

\section{METODE}

Tempat penelitian adalah tempat yang digunakan dalam melakukan penelitian untuk memperoleh data dan keterangan yang akan digunakan. Penelitian ini dilakukan di PT. Wahana Ottomitra Multiartha, Tbk Cabang Madiun, terletak di Jl.Setiabudi No. 51-53 Kota Madiun. Waktu penelitian adalah waktu berlangsungnya penelitian atau saat penelitian ini dilaksanakana. Penelitian ini dilakukan mulai bulan April 2014 sampai dengan Juli 2014

Pendekatan yang digunakan dalam penelitian ini adalah pendekatan kualitatif. Dalam penelitian ini, peneliti melakukan analisis pengendalian intern piutang usaha dengan melakukan analisis terhadap rasio Receivable Turn Over, 
Average Collection Period, Aging of Account Receivable. Penelitian menggunakan metode kualitatif dengan mengambil data berupa keterangan dan penjelasan yang berasal dari pimpinan perusahaan, maupun staff yang berhubungan dengan penelitian kemudian menyajikan, serta menganalisis data sehingga dapat memberikan gambaran yang jelas atas obyek yang diteliti, kemudian dapat ditarik kesimpulan dan pembuatan rekomendasi. Sedangkan jenis penelitian yang digunakan adalah deskriptif komparatif, karena dalam penelitian ini menghitung rasio perputaran piutang dan rasio umur rata-rata piutang yang kemudian dilakukan perbandingan dari periode 2011 sampai dengan periode 2013 .

Data yang dipergunakan dalam penelitian ini adalah : Data primer. Data primer merupakan data yang diperoleh secara langsung dari sumber pertama yaitu pada PT. WOM Finance cabang Madiun. Data primer yang dikumpulkan adalah data dari tahun 2011-2013. Data sekunder. Data sekunder merupakan data pendukung yang bersifat memperkuat hasil analisis. Data ini merupakan data yang sudah ada atau disusun oleh pihak perusahaan, berupa sejarah perkembangan perusahaan, deskripsi jabatan dan struktur organisasi.

Dalam penelitian ini penulis menggunakan teknik pengumpulan data sebagai berikut : Studi dokumentasi dan Wawancara

Prosedur penelitian merupakan urutan langkah-langkah yang harus dilaksanakan oleh peneliti dalam melakukan suatu penelitian. Sebelum melakukan penelitian ada beberapa prosedur yang dilakukan oleh peneliti antara lain:

1. Peneliti mengumpulkan data laporan keuangan perusahaan tiga tahun terakhir ( periode 2011-2013).

2. Peneliti mengolah data-data yang sudah dikumpulkan.

3. Peneliti menganalisis data-data yang sudah ada menggunakan rumusrumus yang sudah ditetapkan.

4. Peneliti menghitung besarnya rasio receivable turn over, average collection period, aging of account receivable pada periode 2011-2013.

5. Peneliti membandingkan besarnya rasio receivable turn over, average collection period, aging of account receivable periode 2011-2013.

6. Peneliti menarik kesimpulan dari pengolahan data serta perbandingan yang sudah dilakukan.

Dalam melakukan penelitian ini, teknik keabsahan data yang digunakan oleh peneliti adalah teknik triangulasi dengan metode dokumentasi dalam pengambilan dan pengecekan data yang diperlukan pada PT. Wahana Ottomitra Multiartha, Tbk cabang Madiun. Menurut Sugiyono (2014:83) menyatakan bahwa triangulasi diartikan sebagai teknik pengumpulan data yang bersifat menggabungkan dari berbagai teknik pengumpulan data dan sumber data yang telah ada. Bila peneliti melakukan pengumpulan data dengan triangulasi, maka sebenarnya peneliti mengumpulkan data yang sekaligus menguji kredibilitas data, yaitu mengecek kredibilitas data dengan berbagai teknik pengumpulan data dan berbagai sumber data.

Teknik analisis yang digunakan dalam penelitian ini adalah teknik analisis kualitatif. Teknik analisis kualitatif ini digunakan untuk mengolah data, baik data primer maupun data sekunder. Penelitian kualitatif adalah penelitian yang menganalisis data dengan cara menentukan, mengumpulkan, mengklarifikasi, 
menganalisis sehingga memberikan gambaran yang jelas mengenai segala sesuatu yang terjadi pada suatu kegiatan atau situasi tertentu. Dalam hal ini peneliti mengambil data laporan keuangan dari PT. Wom Finance yang akan digunakan untuk mengitung rasio Receivable Turn Over, Average Collection Period, Aging of Account Receivable.

Menghitung Perputaran Piutang (Receivable turn over - RTO)

$$
\text { Perputaran piutang }=\quad \frac{\text { penjualan kredit bersih }}{\text { Rata - rata piutang }}
$$

Dimana, untuk menghitung rata-rata piutang adalah

$$
\text { Rata-rata piutang }=\frac{\text { Saldo awal piutang }+ \text { Saldo akhir piutang }}{2}
$$

Menghitung umur rata-rata piutang (Average collection Period)

Umur Rata-rata piutang $=\quad \frac{360 \text { hari }}{\text { perputaran piutang }}$

\section{PEMBAHASAN}

Kriteria untuk mengukur efektivitas pengendalian piutang usaha PT.WOM Finance, Tbk cabang Madiun

Beberapa metode analisis yang digunakan untuk mengukur efektivitas pengendalian piutang usaha PT. WOM Finance, Tbk adalah :

\section{A. Receivable Turn Over (RTO)}

Rasio ini mengukur berapa kali (dalam rata-rata) piutang yang terjadi pada suatu periode tertentu. Periode perputaran piutang adalah periode terikatnya modal dalam piutang yang tergantung dari syarat pembayarannya.

Menghitung Rasio Perputaran Piutang (Receivable Turn Over)

Perputaran piutang $=$

Penjualan kredit bersih

$$
\text { Rata - rata piutang }
$$

Dimana, untuk menghitung rata-rata piutang adalah

$$
\text { Rata-rata piutang }=\frac{\text { Saldo awal piutang }+ \text { Saldo akhir piutang }}{2}
$$

Adapun hasil perhitungan dari perputaran piutang adalah sebagai berikut :

a. Tahun 2011

$$
\text { Perputaran piutang }=\frac{81.227 .671 .010=0.81}{100.345 .368 .173}
$$


b. Tahun 2012

Perputaran piutang $=\frac{67.916 .508 .308=0.63}{107.732 .942 .332}$

c. Tahun 2013

Perputaran piutang $=\frac{74.436 .155 .253=0.73}{102.041 .520 .859}$

Hasil perhitungan RTO diatas dapat dilihat pada tabel 1 berikut :

Tabel 1

Hasil Perhitungan Receivable Turn Over (RTO)

\begin{tabular}{|c|c|c|c|c|}
\hline Tahun & $\begin{array}{c}\text { Penjualan Kredit } \\
\text { (Rp) }\end{array}$ & $\begin{array}{c}\text { Rata-rata Piutang } \\
\text { (Rp) }\end{array}$ & $\begin{array}{c}\text { RTO } \\
\text { (Kali) }\end{array}$ & $\begin{array}{c}\text { Perubahan } \\
\text { RTO }\end{array}$ \\
\hline & & & & \\
2011 & 81.227 .671 .010 & 100.345 .368 .173 & 0.81 & - \\
2012 & 67.916 .508 .308 & 107.732 .942 .332 & 0.63 & $(0.18)$ \\
2013 & 74.436 .155 .253 & 102.041 .520 .859 & 0.73 & 0.10 \\
\hline
\end{tabular}

Dari hasil tabel diatas menunjukkan bahwa kinerja Receivable Turn Over (RTO) mengalami fluktuasi dari tahun ke tahun. Hal ini ditunjukkan pada peningkatan RTO yang terjadi pada tahun 2011 mengalami peningkatan sebesar 0.81 kali. Pada tahun 2012 terjadi penurunan RTO yaitu 0.63 kali atau turun sebesar 0.18 dari tahun sebelumnya. Pada tahun berikutnya, yaitu 2013 mengalami peningkatan RTO sebesar 0.73 atau naik sebesar 0.10 dari tahun 2012.

Kinerja RTO perusahaan mencapai titik tertinggi yaitu pada tahun 2011 sebesar 0.81 kali dan sebaliknya RTO yang terendah pada tahun 2012 sebesar 0.63 atau turun 0.18 . Hal ini disebabkan karena tingkat penjualan kredit yang sangat rendah yaitu sebesar Rp. 67.916.508.308,- yang diikuti oleh rata-rata piutang yang tinggi yaitu sebesar Rp. 107.732.942.332.- sehingga mengakibatkan tingkat RTO perusahaan sangat rendah. Pada tahun 2013, kinerja RTO meningkat menjadi lebih baik dari tahun 2012 yaitu 0.73 kali atau meningkat 0.10 kali. Hal ini disebabkan karena penjualan kredit perusahaan meningkat yaitu dari Rp 67.916.508.308,- pada tahun 2012 menjadi Rp. 74.436.155.253,- dan juga terjadi penurunan total piutang Rp. 107.732.942.332,- pada tahun 2012 menjadi Rp. 102.041.520.859,- pada tahun 2013 ini membuktikan bahwa perusahaan berusaha untuk memperbaiki kinerja piutangnya dengan cara meningkatkan penjualan kreditnya dan mengurangi dengan seminimal mungkin jumlah piutang tak tertagihnya, karena pada dasarnya semakin tinggi tingkat perputaran piutang suatu perusahaan, maka semakin baik pengelolaan piutangnya, dan juga jika tingkat perputaran piutangnya tinggi berarti semakin pendek waktu terikatnya modal dalam piutang.

\section{B. Average Collection Period (ACP)}

Rasio ini berfungsi untuk mengetahui rata-rata hari yang diperlukan untuk mengumpulkan piutang dan mengubahnya menjadi kas. Hasil yang ditetapkan dari perhitungan ini akan dihubungkan dengan jumlah hari yang ditetapkan sebagai standar kredit perusahaan. 
Menghitung umur rata-rata piutang (Average collection Period)

Umur Rata-rata piutang =

360 hari

perputaran piutang

Adapun hasil perhitungan dari ACP adalah sebagai berikut :

a. Tahun 2011

Average Collection Period $=\frac{360}{0.81}=445$

b. Tahun 2012

Average Collection Period $=\frac{360}{0.63}=571$

c. Tahun 2013

Average Collection Period $=\underline{360}=494$

Hasil perhitungan ACP diatas dapat dilihat pada tabel 2 berikut :

Tabel 2

Hasil Perhitungan Average Collection Periode - ACP

\begin{tabular}{|c|c|c|c|}
\hline Tahun & RTO (Kali) & ACP (Hari) & Perubahan ACP \\
\hline & & & \\
2011 & 0.81 & 445 & 126 \\
2012 & 0.63 & 571 & $(77)$ \\
2013 & 0.73 & 494 & \\
\hline
\end{tabular}

Dari hasil tabel diatas terlihat Tingkat Average collection period (ACP) perusahaan sangat dipengaruhi oleh tingkat Receivable Turn Over (RTO) tahun bersangkutan. Semakin besar tingkat RTO perusahaan, maka semakin baik pula nilai ACPnya. Tingkat Average Collection period $(A C P)$ perusahaan yang terbaik pada tahun 2011, yaitu sebesar 445 hari, dimana tingkat perputaran piutangnya pun sangat tinggi. Sedangkan tingkat ACP perusahaan yang terendah adalah pada tahun 2012, dimana tingkat ACPnya mencapai 571 hari, dimana tingkat perputaran piutangnya pun sangat rendah yaitu 0.63 kali. Pada tahun berikutnya yaitu tahun 2013, tingkat ACPnya menurun menjadi 494 hari. Ini menunjukkan kinerja piutang usahanya sudah lebih baik dari tahun 2012 .

\section{Aging Of Account Receivable}

Rasio ini berfungsi untuk mengukur komposisi bucket Account Receivable, dalam rasio ini bucket AR dipisah berdasarkan aging / umur overdue nya. Semakin besar umur tunggakannya berarti semakin buruk kualitas AR tersebut dan berarti semakin besar kemungkinan piutang tak tertagihnya.

Hasil perhitungan Aging of Account Receivable dapat dilihat dapat dilihat pada tabel 3 dibawah ini. 
Anny W, Analisis Pengendalian Intern Piutang Usaha 123

Tabel 2

Hasil Perhitungan Aging of Account Receivable - AAR

*dalam Persentase

\begin{tabular}{|c|c|c|c|}
\hline Bucket & 2011 & 2012 & 2013 \\
\hline NO OD & $81.73 \%$ & $81.90 \%$ & $79.21 \%$ \\
\hline 001_030 & $12.59 \%$ & $13.47 \%$ & $16.45 \%$ \\
\hline $031 \_060$ & $1.85 \%$ & $1.72 \%$ & $1.47 \%$ \\
\hline 061_090 & $1.10 \%$ & $0.50 \%$ & $0.68 \%$ \\
\hline 091_120 & $0.56 \%$ & $0.48 \%$ & $0.46 \%$ \\
\hline $121 \_150$ & $0.55 \%$ & $0.41 \%$ & $0.39 \%$ \\
\hline $151 \_180$ & $0.49 \%$ & $0.66 \%$ & $0.41 \%$ \\
\hline $181 \_210$ & $0.58 \%$ & $0.41 \%$ & $0.39 \%$ \\
\hline $211 \_240$ & $0.36 \%$ & $0.39 \%$ & $0.34 \%$ \\
\hline $241 \_270$ & $0.05 \%$ & $0.06 \%$ & $0.14 \%$ \\
\hline $271 \_300$ & $0.03 \%$ & $0.00 \%$ & $0.04 \%$ \\
\hline 301_UP & $0.13 \%$ & $0.00 \%$ & $0.02 \%$ \\
\hline Aging 30+ & $5.68 \%$ & $4.63 \%$ & $4.35 \%$ \\
\hline Aging 90+ & $2.73 \%$ & $2.41 \%$ & $2.19 \%$ \\
\hline Aging 120 & $2.18 \%$ & $1.93 \%$ & $1.73 \%$ \\
\hline Aging 180+ & $1.14 \%$ & $0.86 \%$ & $0.92 \%$ \\
\hline
\end{tabular}

Dari tabel Aging of Account Receivable diatas menunjukkan bahwa rasio Aging of Account Receivable mengalami perbaikan aging dari tahun ke tahun. Hal ini menunjukkan bahwa kualitas booking customer dan penagihan mengalami perbaikan dari tahun ke tahun, hal tersebut menunjukkan bahwa pengendalian intern yang dilakukan oleh perusahaan menunjukkan progress yang baik dari tahun ke tahun.

Tabel 4

Evaluasi Pengendalian Intern Piutang Usaha PT.Wahana Ottomitra Multiartha, Tbk cabang Madiun

\begin{tabular}{|l|l|c|c|}
\hline No & & Ya & Tidak \\
\hline I & Job Description & & \\
\hline 1 & $\begin{array}{l}\text { Apakah terdapat struktur organisasi dan job description yang } \\
\text { jelas dalam pelaksanaan tugas dan wewenang? }\end{array}$ & $V$ & \\
\hline 2 & $\begin{array}{l}\text { Apakah terdapat divisi khusus dicabang untuk menangani } \\
\text { penyelesaian kredit bermasalah? }\end{array}$ & $V$ & \\
\hline
\end{tabular}




\begin{tabular}{|c|c|c|c|}
\hline No & & $\mathbf{Y a}$ & Tidak \\
\hline 3 & $\begin{array}{l}\text { Apakah terdapat pemisahan tugas antara account officer } \\
\text { dengan fungsi yang melakukan analisis kredit dalam } \\
\text { permohonan kredit? }\end{array}$ & $V$ & \\
\hline 4 & $\begin{array}{l}\text { Apakah terdapat pemisahan tugas antara appraisal dengan } \\
\text { yang melakukan analisis kredit dalam permohonan kredit? }\end{array}$ & $V$ & \\
\hline 5 & $\begin{array}{l}\text { Apakah prosedur pengawasan kredit dilakukan oleh suatu } \\
\text { bagian khusus? }\end{array}$ & $V$ & \\
\hline II & Sistem dan Prosedur & & \\
\hline $\mathbf{A}$ & Prosedur Permohonan kredit & & \\
\hline 1 & $\begin{array}{l}\text { Apakah WOM Finance memiliki Standar Operasional di } \\
\text { bidang perkreditan? }\end{array}$ & $V$ & \\
\hline 2 & $\begin{array}{l}\text { Apakah data yang diberikan oleh pemohon kredit sebelum } \\
\text { dianalisis diperiksa dulu kelengkapan legalitasnya? }\end{array}$ & $V$ & \\
\hline 3 & $\begin{array}{l}\text { Apakah formulir permohonan kredit diisi secara lengkap dan } \\
\text { tepat oleh calon debitur dan pengisiannya dilakukan pada saat } \\
\text { survey? }\end{array}$ & $V$ & \\
\hline 4 & $\begin{array}{l}\text { Apakah surveyor menjelaskan paham kredit kepada calon } \\
\text { debitur? }\end{array}$ & & $V$ \\
\hline 5 & $\begin{array}{l}\text { Apakah aktivitas usaha calon debitur perlu diketahui dan } \\
\text { perlu dilakukan survey ke tempat usaha/kerja calon debitur? }\end{array}$ & $V$ & \\
\hline 6 & $\begin{array}{l}\text { Apakah WOM Finance memeriksa calon debitur dalam daftar } \\
\text { kredit macet(black list)? }\end{array}$ & $V$ & \\
\hline B & Prosedur Analisis Kredit & & \\
\hline 1 & $\begin{array}{l}\text { Apakah sudah diterapkan scoring system secara benar untuk } \\
\text { mempercepat proses persetujuan kredit? }\end{array}$ & $V$ & \\
\hline 2 & $\begin{array}{l}\text { Apakah data bad customer info selalu diupdate dari sumber } \\
\text { data yang sifatnya nasional? }\end{array}$ & $V$ & \\
\hline 3 & $\begin{array}{l}\text { Apakah field auditor telah melakukan pengecekan untuk } \\
\text { memastikan bahwa prosedur kerja telah dilaksanakan oleh } \\
\text { bagian terkait? }\end{array}$ & $V$ & \\
\hline 4 & $\begin{array}{l}\text { Apakah dalam melakukan analisis kredit telah diterapkan } \\
\text { prinsip 5C? }\end{array}$ & $V$ & \\
\hline $\mathbf{C}$ & Prosedur Pengambilan Keputusan & & \\
\hline 1 & $\begin{array}{l}\text { Apakah pemutusan kredit didukung oleh analisa dan prosedur } \\
\text { kredit yang biasa dilakukan? }\end{array}$ & $V$ & \\
\hline 2 & $\begin{array}{l}\text { Apakah ketentuan mengenai limit otorisasi pemberian kredit } \\
\text { untuk pimpinan cabang telah dilaksanakan dengan baik dan }\end{array}$ & $V$ & \\
\hline
\end{tabular}


Anny W, Analisis Pengendalian Intern Piutang Usaha 125

\begin{tabular}{|c|c|c|c|}
\hline No & & Ya & Tidak \\
\hline & konsisten? & & \\
\hline 3 & $\begin{array}{l}\text { Apakah rekomendasi kredit ditandatangani oleh pimpinan } \\
\text { cabang untuk kredit yang telah disetujui? }\end{array}$ & $V$ & \\
\hline 4 & $\begin{array}{l}\text { Apakah data dari setiap calon debitur baik yang diterima } \\
\text { maupun yang ditolak selalu diinput datanya? }\end{array}$ & $V$ & \\
\hline $\mathbf{D}$ & Prosedur Penagihan & & \\
\hline 1 & $\begin{array}{l}\text { Apakah secara periodik pimpinan cabang menerima laporan } \\
\text { tentang kredit yang jatuh tempo dan kredit yang tertunggak? }\end{array}$ & $V$ & \\
\hline 2 & $\begin{array}{l}\text { Apakah collector telah melakukan penagihan selama bulan } \\
\text { berjalan dan tidak terkonsentrasi diakhir bulan saja? }\end{array}$ & & $V$ \\
\hline 3 & $\begin{array}{l}\text { Apakah untuk setiap transaksi pembayaran menggunakan } \\
\text { kwitansi rangkap dan teregister system? }\end{array}$ & $V$ & \\
\hline 4 & $\begin{array}{l}\text { Apakah prosedur penarikan barang dilaksanakan sesuai } \\
\text { dengan ketentuan? }\end{array}$ & $V$ & \\
\hline 5 & $\begin{array}{l}\text { Apakah ada dokumen yang menunjukkan bahwa debitur telah } \\
\text { melakukan pembayaran angsuran kredit? }\end{array}$ & $V$ & \\
\hline III & Prosedur dan ketentuan yang sehat & & \\
\hline 1 & $\begin{array}{l}\text { Apakah semua dokumen asli disimpan dalam lemari besi } \\
\text { tahan api? }\end{array}$ & $V$ & \\
\hline 2 & $\begin{array}{l}\text { Apakah tersedia tempat / ruangan khusus untuk menyimpan } \\
\text { dokumen-dokumen perkreditan secara aman dan tertib? }\end{array}$ & $V$ & \\
\hline 3 & $\begin{array}{l}\text { Apakah motor yang disita,dipakai untuk kegiatan } \\
\text { operasional? }\end{array}$ & & $V$ \\
\hline 4 & Apakah diadakan mutasi pegawai secara teratur? & & $V$ \\
\hline 5 & Apakah arus keluar masuk karyawan rendah? & $V$ & \\
\hline 6 & Apakah komunikasi antar bagian cukup baik? & $V$ & \\
\hline 7 & $\begin{array}{l}\text { Bila ada perubahan data debitur,apakah sudah dilakukan } \\
\text { pencatatan atas perubahan tersebut? }\end{array}$ & & $V$ \\
\hline 8 & $\begin{array}{l}\text { Apakah staff administrasi melakukan pencatatan atas setiap } \\
\text { pembayaran angsuran dari para debitur? }\end{array}$ & $V$ & \\
\hline 9 & $\begin{array}{l}\text { Apakah ada tindakan disiplin yang tegas bagi karyawan dan } \\
\text { pejabat WOM Finance yang dengan sengaja terlibat dalam } \\
\text { kasus Fraud? }\end{array}$ & $V$ & \\
\hline 10 & $\begin{array}{l}\text { Apakah setiap karyawan dan pejabat WOM Finance bisa } \\
\text { memperoleh file dan dokumen kredit? }\end{array}$ & & $V$ \\
\hline
\end{tabular}




\begin{tabular}{|c|c|c|c|}
\hline No & & Ya & Tidak \\
\hline 11 & $\begin{array}{l}\text { Apakah karyawan lain dapat mengetahui password pada } \\
\text { komputer? }\end{array}$ & & $V$ \\
\hline IV & Pegawai yang kompeten & & \\
\hline 1 & $\begin{array}{l}\text { Apakah setiap karyawan memiliki pengetahuan atau } \\
\text { kecakapan yang sesuai dengan tugas dan tanggung jawab } \\
\text { masing-masing? }\end{array}$ & $V$ & \\
\hline 2 & $\begin{array}{l}\text { Apakah setiap karyawan mengetahui tugas dan } \\
\text { tanggungjawabnya dengan baik? }\end{array}$ & $V$ & \\
\hline 3 & $\begin{array}{l}\text { Apakah sebelum karyawan dan pejabat bank ditempatkan di } \\
\text { bagian diberikan pelatihan/arahan mengenai perkembangan } \\
\text { kredit? }\end{array}$ & $V$ & \\
\hline 4 & $\begin{array}{l}\text { Apakah setiap karyawan diberikan kesempatan jenjang } \\
\text { karier? }\end{array}$ & $V$ & \\
\hline
\end{tabular}

\section{KESIMPULAN}

Secara keseluruhan, prosedur pengendalian intern terhadap piutang usaha pada PT.WOM Finance, Tbk cabang Madiun berjalan cukup efektif. Pembagian tugas dan wewenang sudah sesuai dengan job description masing-masing, penerapan SOP dilakukan pada semua divisi untuk meminimalkan kecurangan / fraud. Tingkat piutang tak tertagih cabang Madiun menunjukkan perbaikan dengan total piutang tak tertagih tahun 2013 sebesar $3.58 \%$, piutang yang dapat ditagih selama periode 2013 sebesar $96.42 \%$. Hal ini menunjukkan bahwa dengan dilakukannya pengendalian intern terhadap piutang usaha, kualitas booking AR dan kualitas penagihan mengalami perbaikan terus menerus sehingga dapat meminimalkan piutang tak tertagihnya dan berhasil membukukan profit sesuai dengan tujuan yang ditetapkan oleh perusahaan.

\section{Saran}

1. Dalam melakukan survey dan analisa kepada calon debitur, surveyor harus lebih memperhatikan kondisi calon debitur tersebut apakah memenuhi persyaratan atau tidak sehingga layak untuk dilakukan pembiayaan dengan memperhatikan aspek 5C serta wajib menjelaskan mengenai paham kredit kepada calon debitur. Diharapkan dengan debitur yang berkualitas, maka jumlah bad customer dan piutang tak tertagih menjadi semakin kecil.

2. Perusahaan sebaiknya melakukan rotasi atau mutasi kerja secara berkala sehingga dengan adanya rotasi atau mutasi kerja akan mengurangi rasa jenuh dalam bekerja, selain itu juga merupakan tindakan untuk menilai apakah karyawan telah bekerja sesuai dengan peraturan dan prosedur yang telah ditetapkan oleh perusahaan sehingga dapat mengurangi risiko kecurangan / lapping yang dilakukan oleh karyawan. 
Anny W, Analisis Pengendalian Intern Piutang Usaha 127

\section{DAFTAR PUSTAKA}

Riyanto, Bambang. 2013. Dasar-dasar Pembelanjaan Perusahaan: BPFE. Yogyakarta

Farah Margaretha.2011.Manajemen Keuangan Untuk Manajemen Non Keuangan. Erlangga : Jakarta.

I Made Sudana. 2011. Manajemen Keuangan Perusahaan Teori dan Praktik. Erlangga : Jakarta.

Munawir. 2004. Analisis Laporan Keuangan . Liberty :Yogyakarta.

Ahmad Syafii Syakur.2009.Intermediate Accounting.Jakarta : AV Publiser.

Rudianto . 2012. Pengantar Akuntansi. Konsep dan Teknik Penyusunan Laporan Keuangan. Erlangga: Jakarta

K.R.Subramanyam dan John J.Wild. 2008. Analisis Laporan Keuangan Edisi Kesepuluh. Jakarta : Salemba Empat.

Sugiyono.2014. Memahami Penelitian Kualitatif.Bandung : Alfabeta.

K.R.Subramanyam, John J.Wild, Halsey. 2005. Analisis Laporan Keuangan Edisi Delapan. Salemba Empat : Jakarta

Mulyadi. 2001. Sistem Akuntansi. Salemba Empat : Jakarta

DR. (Chand) Taswan. 2010. Manajemen Perbankan. UPP STIM YKPN Yogyakarta.

Jurnal Nabila Habibie. 2013. Analisis Pengendalian Intern Piutang Usaha pada PT. Adira Finance cabang Manado. Universitas Sam Ratulangi.

Jurnal Ticke Fandarani.2012. Analisis Pengendalian Internal Atas Penjualan Kredit dan Piutang Usaha Pada PT.Mitra Sejati Beribu. Jakarta :Universitas Bina Nusantara 